\title{
The qanat of Algerian Sahara: an evolutionary hydraulic system
}

\author{
Boualem Remini $\cdot$ Bachir Achour $\cdot$ Jean Albergel
}

Received: 3 January 2014/Accepted: 22 April 2014/Published online: 13 May 2014

(C) The Author(s) 2014. This article is published with open access at Springerlink.com

\begin{abstract}
This article discusses for the first time a study on the connection and interconnection of qanats located in the Algerian Sahara. During the missions in the oases of Touat and Gourara in 2009, 2010 and 2011, we have been impressed by the complexity of the network of water distribution. The seguias of differents sections take all the senses. Connections are made between qanats to ensure water supply to each owner. In this study, we identified nine models for connecting qanats.
\end{abstract}

\section{Keywords Qanat - Seguia · Network · Distribution ·} Connection

\section{Introduction}

The oases of Touat and Gourara located in hyper-arid regions of the Algerian Sahara. They are known by the rarity of rainfall and the absence of surface water. To live in these areas, farmers exploit the water of the basement. They dug subterranean galleries (qanats) for collecting the water from the aquifer of Intercalary Continental. The water flows by gravity to the gardens. This ingenious

B. Remini ( $\square)$

Department of Water Sciences, Blida University, 9000 Blida,

Algeria

e-mail: reminib@yahoo.fr

B. Achour

Department of Hydraulic, Biskra University, 7000 Biskra,

Algeria

e-mail: bachir.achour@larhyss.net

J. Albergel

Research Institute of Development, Montpellier, France

e-mail: Jean.Albergel@ird.fr technique is called foggara that resembles of qanat of Iran (Goblot 1963, 1979; Abouei 2006) and Khettara of Morocco (Lighhtfoot 1996; Ben Brahim 2003). This hydraulic system was developed in the southwestern Iranian plate since 3,000 years. Then it spread across 35 countries in the world (Hofman 2007; Adin 2006).

The qanat is an immense hydraulic apparatus consists of three parts: capture, transport and distribution. The capture and transport of water are delivered through a network of underground tunnels equipped with a multitude of ventilation wells of the gallery. As for the distribution of water is ensured by a complex network of seguias and kasriates.

During the years, social organization is established around the qanat. Water is the real property or each owner can sell, buy or rent its share of water. This has created changes in the distribution network of interconnections and connections between qanats. In this study, we are interested in types of connections between qanats oases of Touat and Gourara during 10 centuries of service.

\section{Study site and data used}

We used data of qanats enumerated in the last census conducted by the NAWR during the period: 1998-2001. Qanats concerned by the operations of connections are located in the regions of Touat and Gourara at 1,000 km southwest of Algiers (Fig. 1).

In 2001, NAWR has inventoried 907 operational qanats. In 2012, this number was revised downwards. According to the information, we obtained from the ksourienne population and owners of qanats despite some rehabilitated of qanats, the number does not exceed 880 service qanats. 


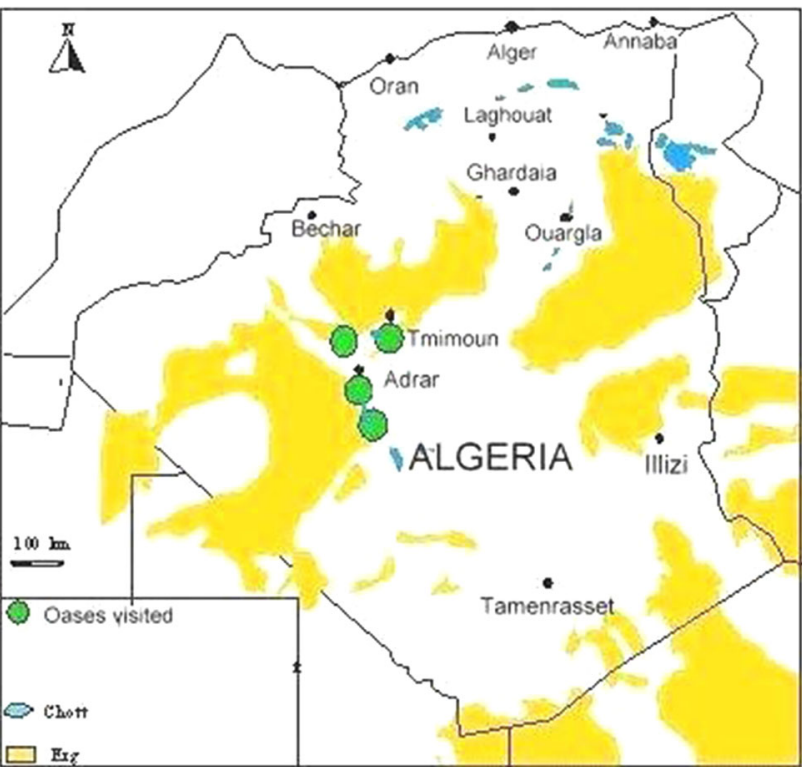

Fig. 1 Study sites

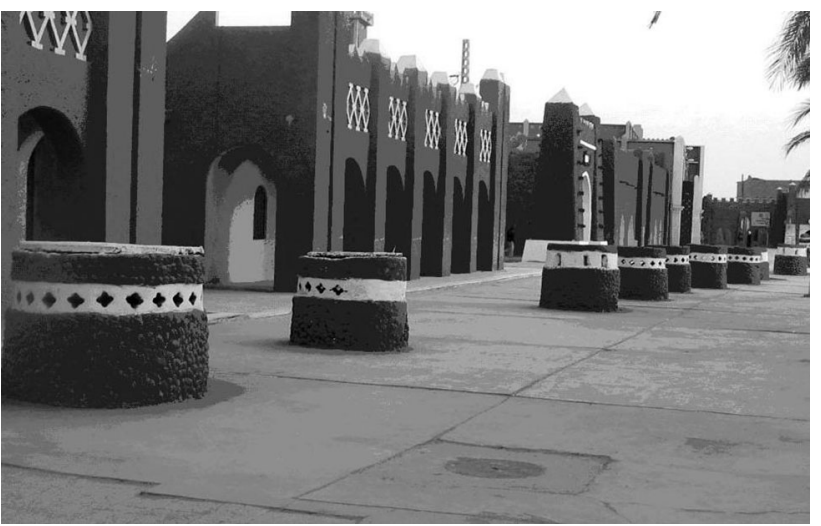

Fig. 2 Well aligned in the city center of Adrar indicator of passage of an underground gallery

\section{Results and discussion}

The oases of Touat and Gourara located in hyper-arid regions of the Algerian Sahara or low rainfall throughout the year. The only source of water in such an environment is stored in the aquifer of Intercalary Continental. It is in this Albian aquifer that farmers went to get the water using a large hydraulic device known as the qanats. It is in this Albian aquifer that farmers went to get the water using a large hydraulic apparatus known as the foggaras (qanat). The system consists of an underground gallery of low slope equipped with a multitude of ventilation shafts. The qanat transfers water from the water to the gardens so as to ensure gravity flow (Fig. 2). Once the water reaches the surface at the entrance of the palm grove, it will be returned between the owners of a

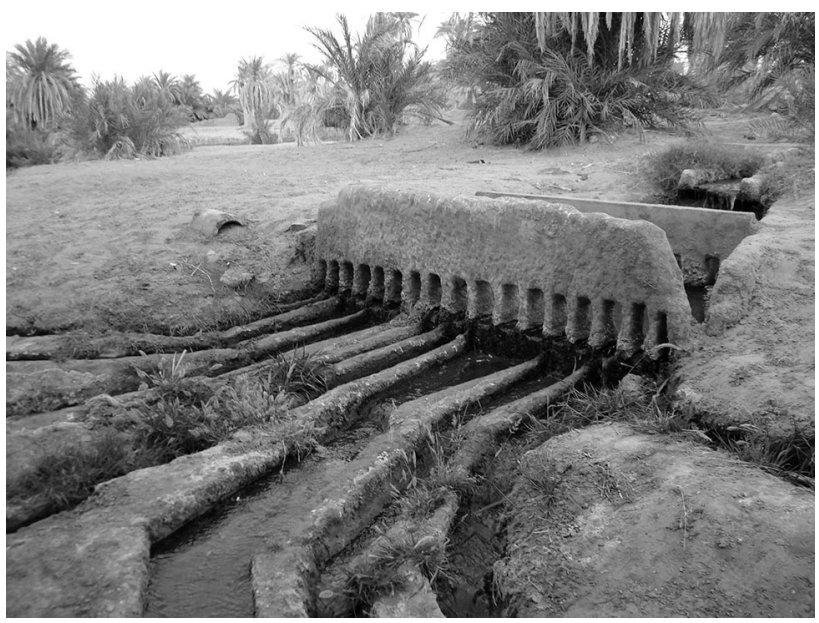

Fig. 3 Secondary kasria of the foggara of El Meghier (Timimoun)

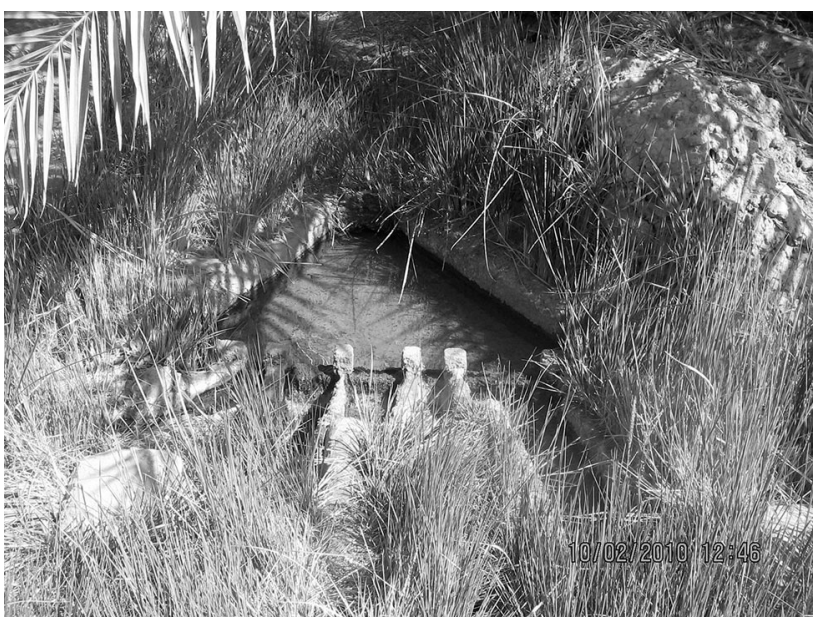

Fig. 4 Seguia in the oasis of Timimoun

equitable thanks to the kasria (Remini et al. 2011; Remini and Achour 2013) (Fig. 3). Downstream of kasria, a water distribution network has been realized in the form of entanglement.

It is composed of several thousand meters of seguias and kasriates of different dimensions (secondary, tertiary and multiple) which supply numerous madjens around which are grouped of guemouns of culturing (Figs. 4, 5, $6,7)$.

The qanat has two functions: technical and social. Kasria separates the two functions and represents the centerpiece of the qanat system. The social organization is created around the kasria. The sharing of water between the owners occurs around the kasria. The Kial el ma measures the flow of each owner with the aid of a measuring instrument called the Louh (Fig. 8). The shares of water are saved and stored in a register (the Zemmam) to be guarded at the person responsible for qanat. In a hot area like Touat and Gourara, water remains the real property: it is bought 


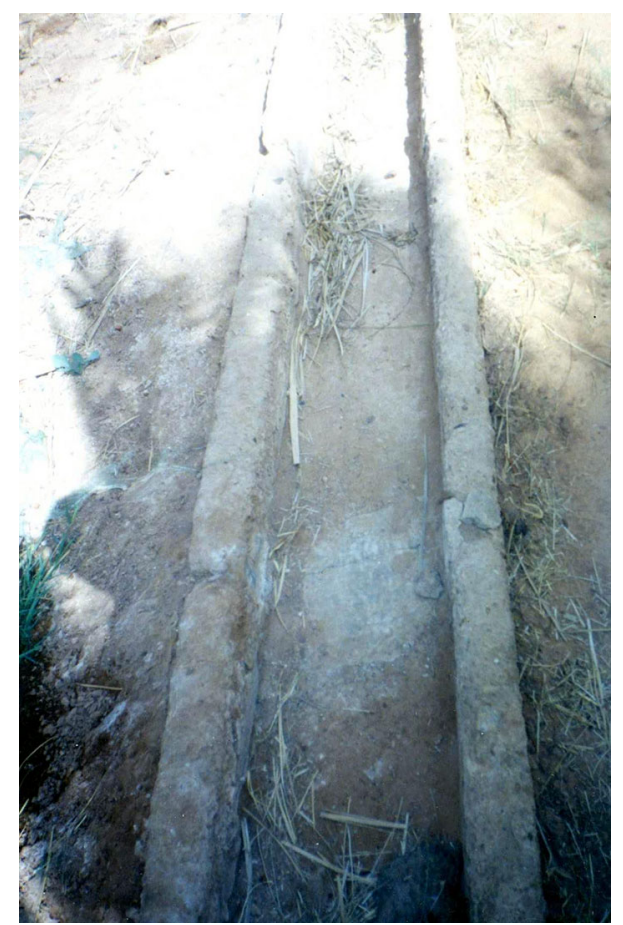

Fig. 5 Kasria tertiary in the oasis of Timimoun

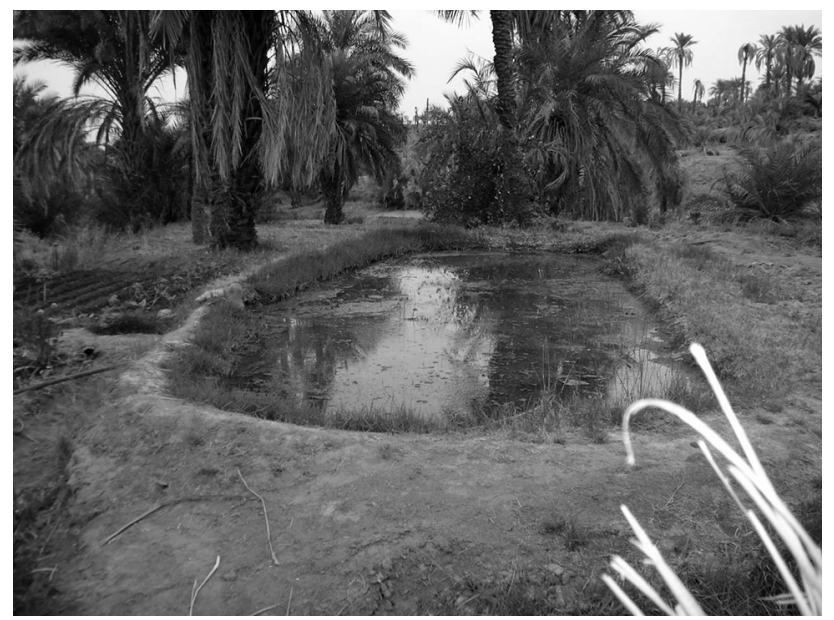

Fig. 6 Madjen in the oasis of Timimoun

and sold. Over the years, the qanat has become a Hydraulic scholarship. The owners who are shareholders may have of parts of water in one or more qanats. This will complicate the distribution network by the connection between the qanats. These operations are repeated connections continuously throughout the year; we are witnessing developments in network seguias by deleting the extension and widening of new seguias.

During our missions in 2009, 2010 and 2011 in the oasis of Touat and Gourara, we were impressed by the ingenuity and technical progress in the transfer and

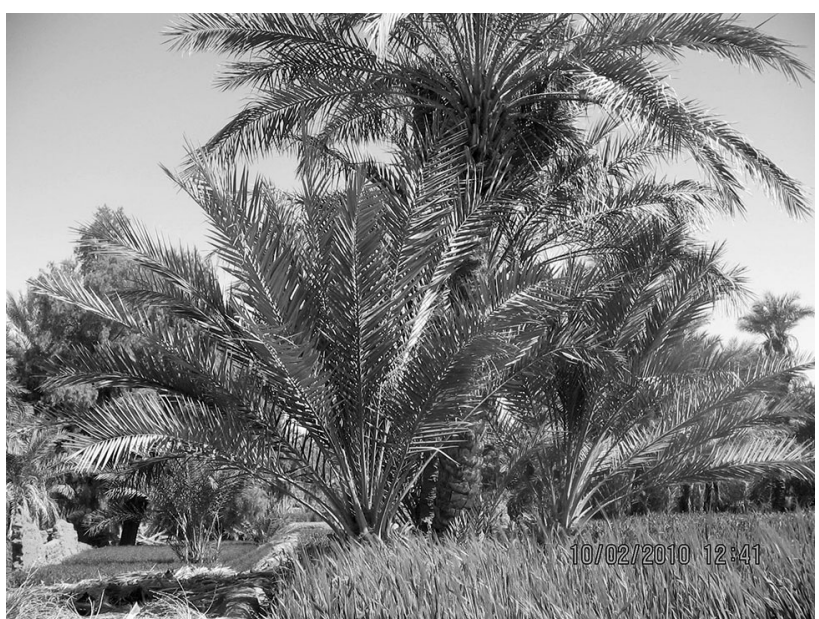

Fig. 7 Guemoun in the oasis of Timimoun

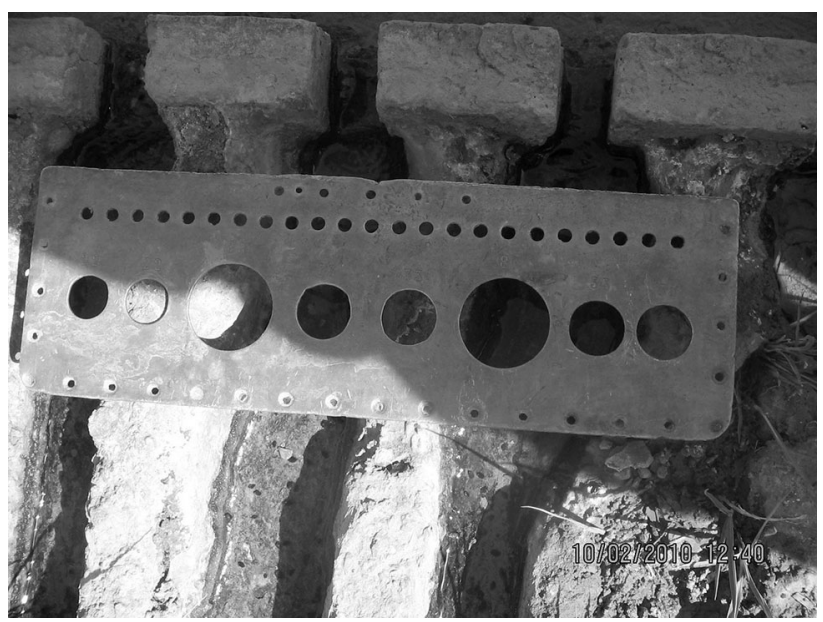

Fig. 8 Gauging plate (Louh) used in the oasis of Timimoun

interconnections between the qanats. Distribution does not stop just seguias, but it is a real branched network of several kilometers seguias different dimensions. The water flows in all directions to reach madjens and guemouns from a kaseria or more kasriates. Owners who hold shares in several qanats water. Thus, they create of seguias to drain water to the gardens. We found in the oases of Touat and Gourara qanats which are connected upstream or downstream of the kasria by one or two seguias. The connection of qanats is made in two ways: kasria irrigation channel or irrigation channel. They create a real complex network forming a tangle of seguias. It is a scalable network in time. The shareholders of a qanat can buy, sell or lease their shares of water. There is a real hydraulic scholarship. Each transaction of purchase or sale is a change at seguias. The entire process (ente or purchase) will be followed by a companion measures and updating the flow of water sold or purchased parts. All the team of 


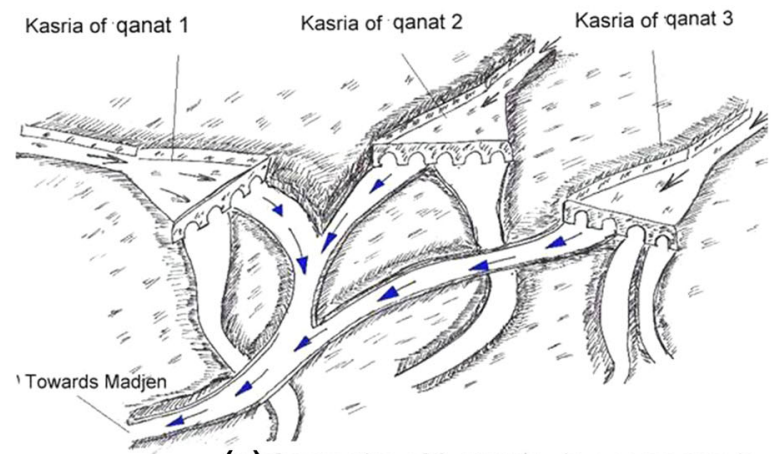

(a) Connection of 3 qanats in a same seguia
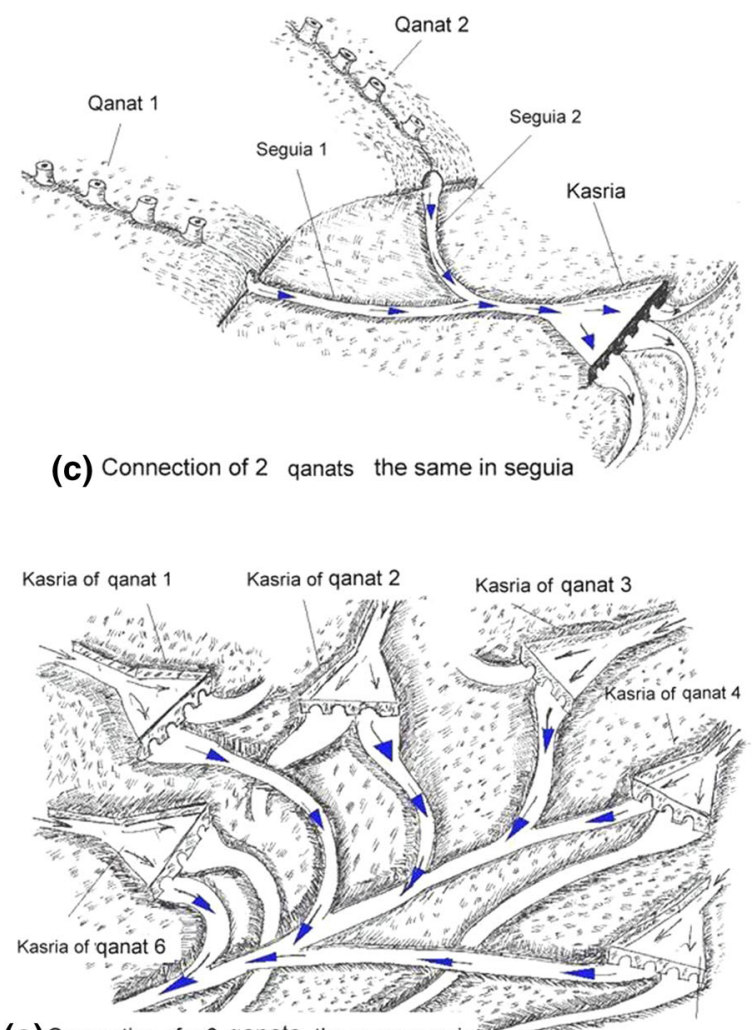

(e) Connection of a 6 qanats the same seguia Kasria of qanat 5

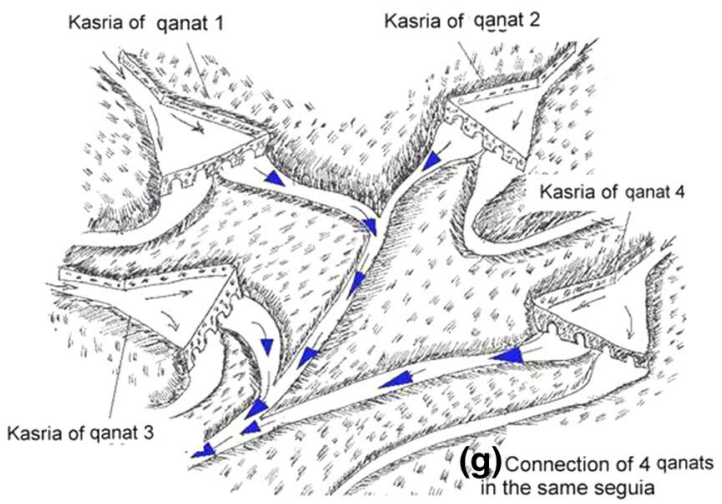

Fig. 9 Models used in connection in the oasis of Touat and Gourara

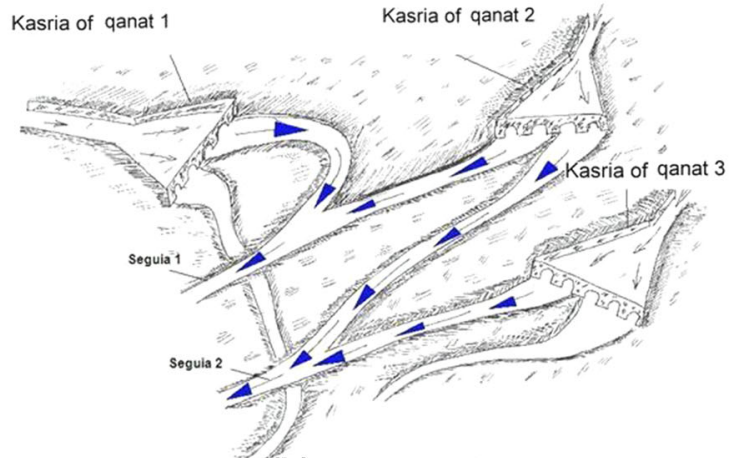

(b) Connection of 3 qanats in two seguias
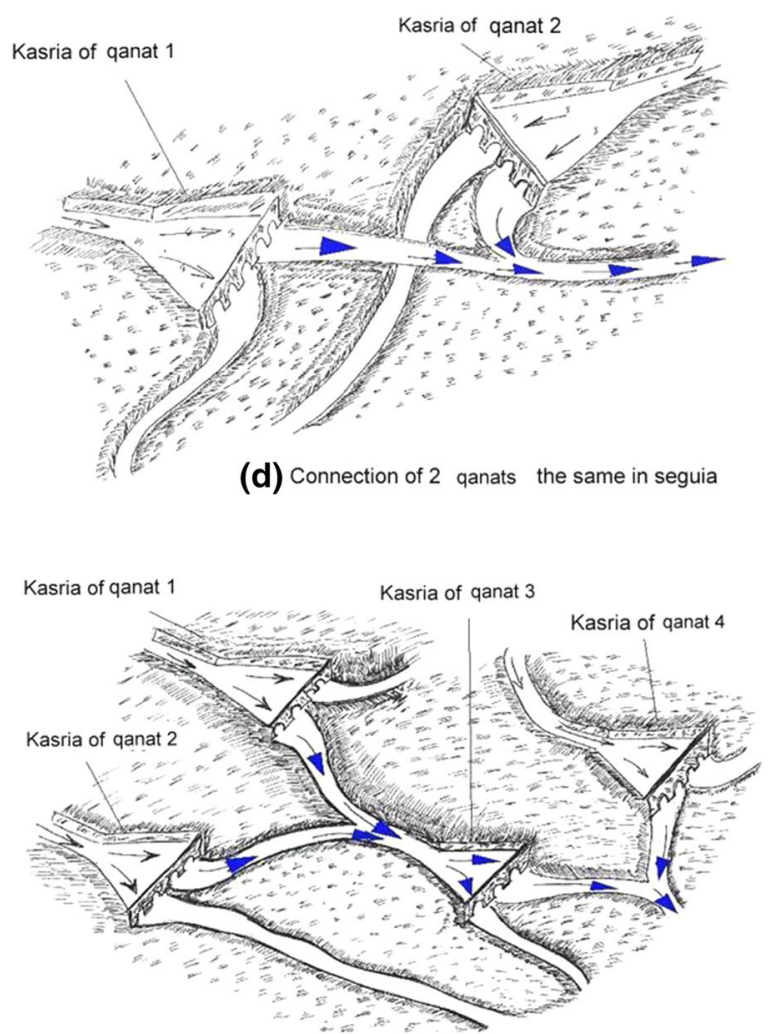

(f) Connection of 4 qanats : two in a the same kesria and two in the same seguia

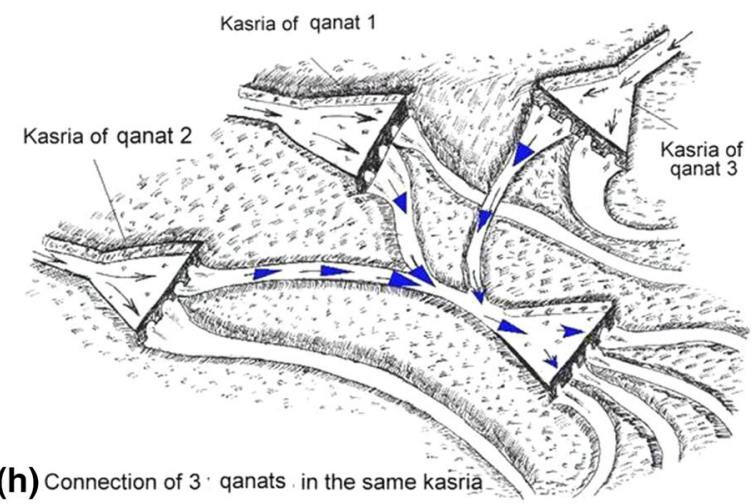


Fig. 10 Synoptic diagram of connection of foggaras : Bekhari and Hadj Mebarek (Reggane)
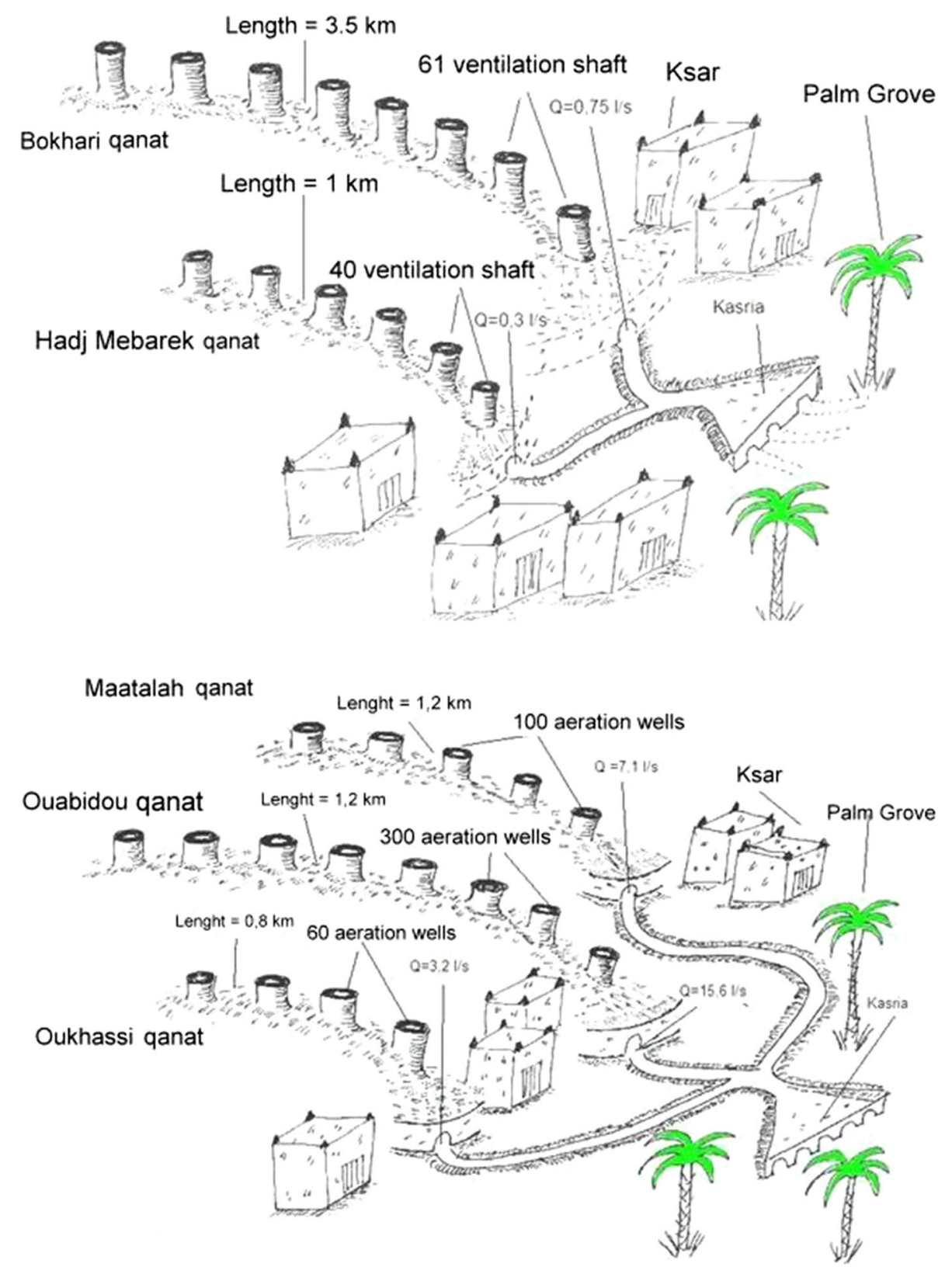

Fig. 11 Synoptic diagram of connection of foggaras : Ouabidou, Maatalah and Oulehassi (Reggane)
Kial el Ma and Chouhouds participate in this event. The qanats system consists of two parts: collection and distribution system is a collective living.

Based on the observation on land surveys of the local population and the use of the latest census data qanats conducted between 1998 and 2001 by the NAWR, connecting of qanats evolves over time, starting of 2-6 qanats. We generated two types of connection:

- At the upstream of the kasria.

- Downstream of the kasria.

About 50 cases of connection between qanats were made in the oasis of Touat and Gourara; 30 types of connections of 2 qanats, 10 types of connections of 3 qanats, 1 case of connecting of 5 qanats and 1 case of connection of 6 qanats. Eight types of connections have been adopted by farmers in the regions of Touat and Gourara as shown in Fig. 9. In the oasis of Regagane, qanats of Belchari and Hadj Mebarek are connected by seguias in one kasria (Fig. 10). In the oases, qanats of Ouabidou, Maatalah and Oulehass are met in a kasria (Fig. 11). In the oasis Zet Kounta, four qanats are connected in qanat of Tgaza (Fig. 12). In the oasis of Zet Kounta, five qanats are attached to the qanat of Ouled Ahmed (Fig. 13). Generally, the qanats coming together in a downstream irrigation channel exhibit a complex pattern as in the case of qanats of Ouzziane and Djeffara coming together downstream of the main kasria (Fig. 14). 
Fig. 12 Synoptic diagram of the mother foggaras of Tgaza

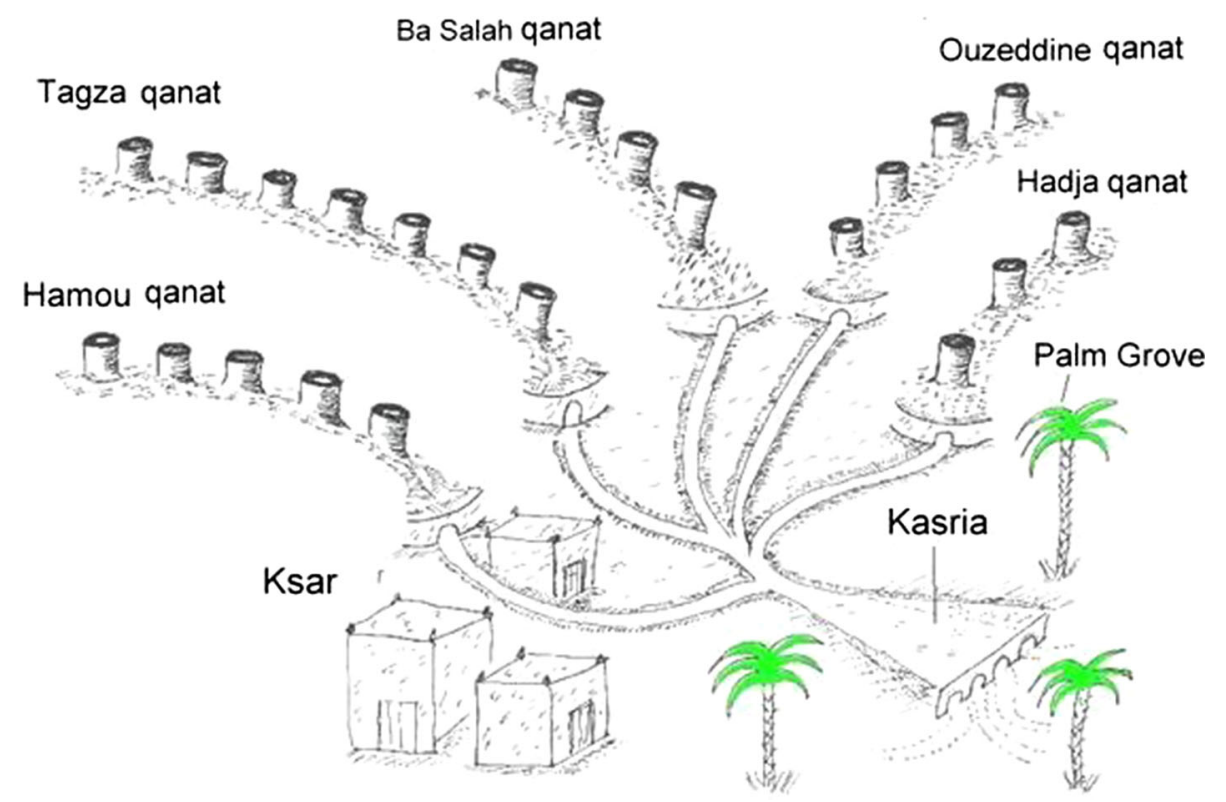

Fig. 13 Foggara Ouled Ahmed (Zet Kaunta)

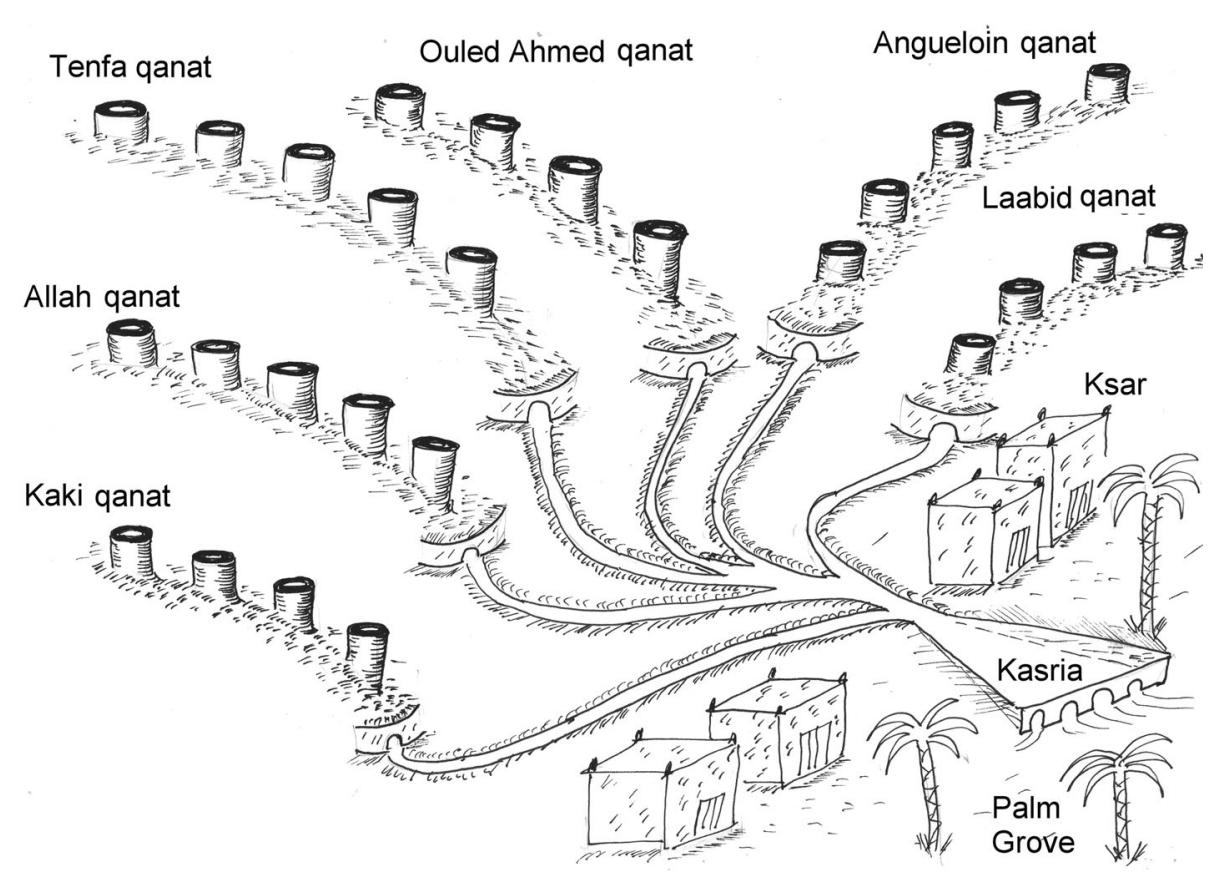

In the oases of Ouled Said (Timimoun), connection: seguia-seguia downstream of the kasria operated in three qanats: Tadgha, Amokrane and Entrite remains a very good example of the mastery of distribution of share water between the different shareholders (Figs. 15, 16).

\section{Conclusion}

Composed of two parts: collection and distribution, qanats are a dynamic hydraulic system. It is scalable in time and depending on the application. The upstream portion consisting essentially of a drainage gallery whose extension never stops in time. The downstream portion composed of a network of seguias that multiply over time. This dynamic is created by the shareholders of the transactions qanats. In an arid environment such as hyper Touat and Gourara, the value of water is greater than that of the earth; water is bought, sold and rented. The qanat is considered a hydraulic scholarship. There are owners who have shares in several qanats at once. To route the waters of these qanats in the garden, these qanats are connected by seguias. New 
Fig. 14 Block diagram of the connection of foggaras Ouzziane and Djaffara

Fig. 15 Synoptic diagram of the connection of 3 foggaras

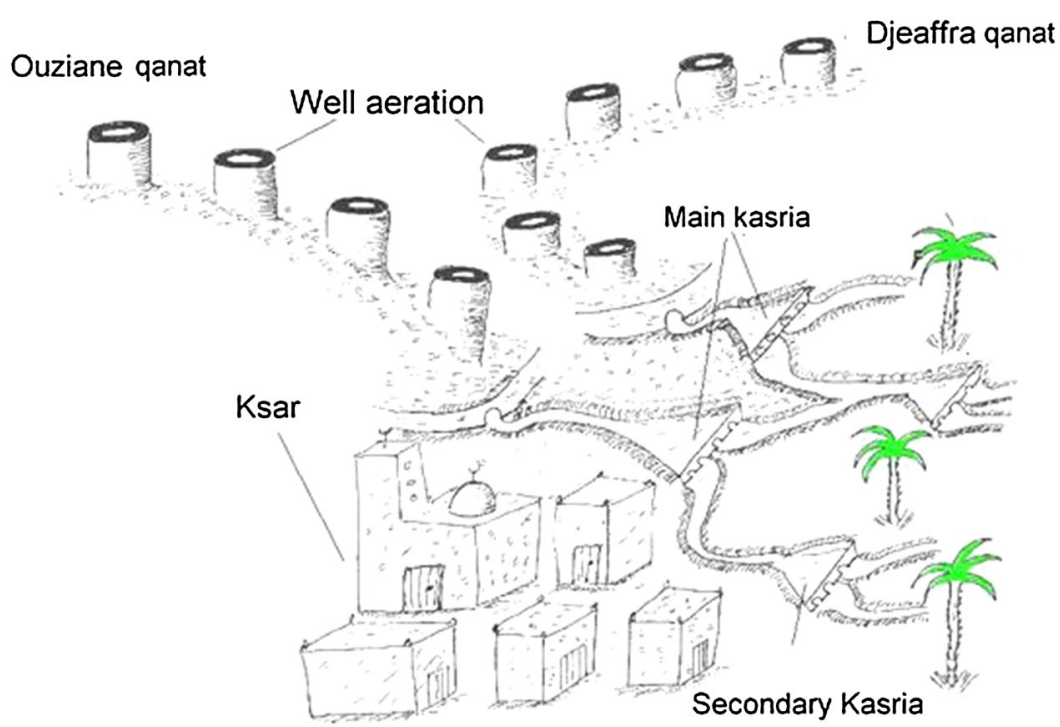

Amokrane qanat

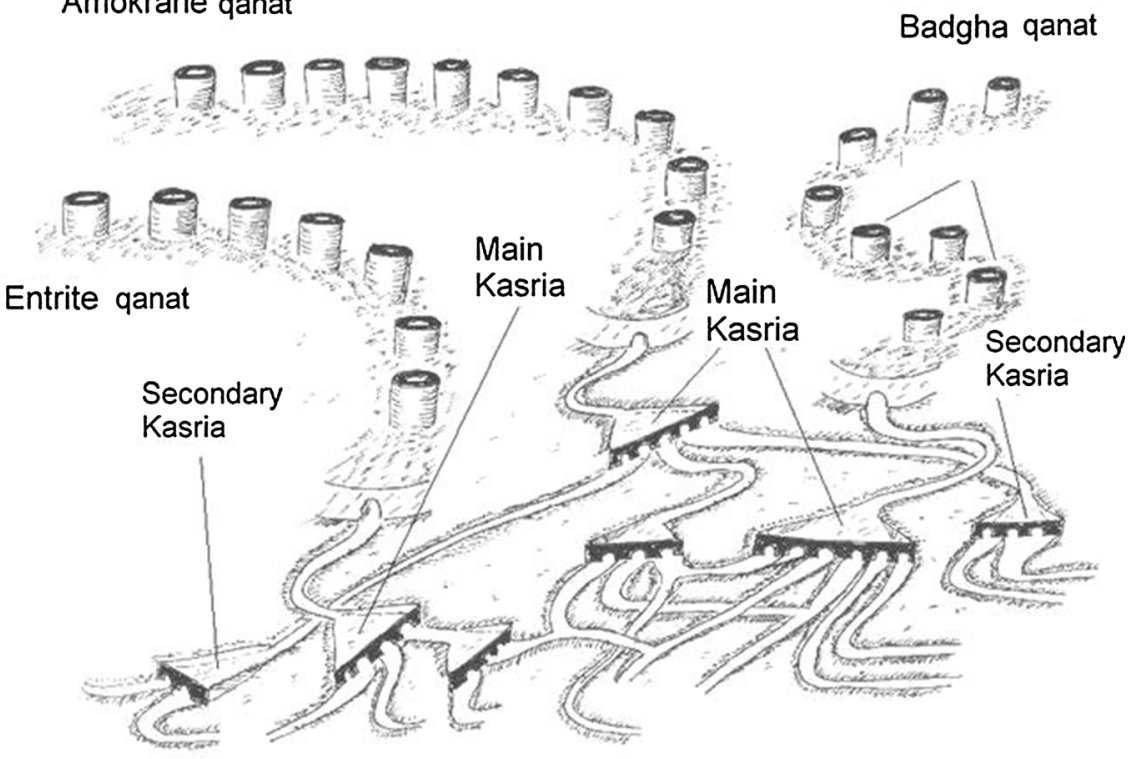

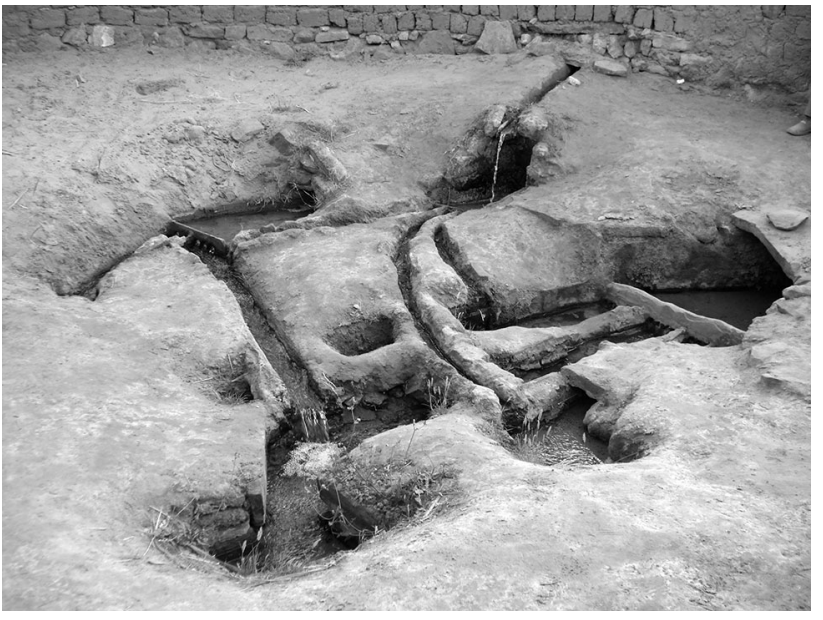

Fig. 16 Connecting foggaras Entrite, Amokrane and Badgha models have been shown to consist of two types of connection: upstream and downstream of the kasria.

Acknowledgments I thank the National Agency for Water Resources me have facilitated access to data. I thank the people of the oasis Timimoun, Adrar and In Salah for their help during our stays.

Open Access This article is distributed under the terms of the Creative Commons Attribution License which permits any use, distribution, and reproduction in any medium, provided the original author(s) and the source are credited.

\section{Glossary}

Chouhouds Plural of Chahad. This is the witness El Hassab The person responsible for calculating of rates

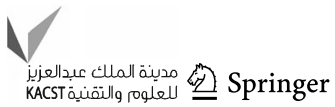




\section{Guemoun Garden \\ Kasriates Plural of kasria-Small triangular basin equipped with a diverter comb \\ Kial el Ma The person who is responsible for measurement of discharge \\ Ksar Houses of farmers \\ Louh Copper plate equipped with openings of different diameters. This flowmeter is the qanat \\ NAWR National Agency for Water Resources \\ Souagui Plural of seguia: channel earth \\ Zemmam Register of Kial El Ma}

\section{References}

Abouei R, (2006) Conservation of badgires and qanats in Yazd central, Iran. The 23rd conference en passive and low Energy Architecture, Geneve, switzerland, 6-8 September
Adin S, (2006). Qanat a unique groundwater management tool in arid regions: the case of Bam region in Iran. In: International symposium groundwater sustainability

Ben Brahim M, (2003). Khettaras of Tafilat: past, present and future. In: International communication Frontnus-Symposium, Walferdange, Luxembourg, 2-5 October

Goblot H (1963) In ancient Iran, the techniques of water and great story. Annals 18(3):499-520

Goblot H (1979) Qanats: a technique of acquisition of water. Mouton, Paris

Hofman A, (2007). Traditional water management by qanat in Iran is compatible with the concept of Gire. Technical synthesis, Engref center of Montpellier

Lighhtfoot DR (1996) Moroccan khettara: traditional Irrigation and progressive desiccation. Geoforum 27(2):261-273

Remini B, Bachir Achour (2013) The qanat of the greatest western Erg. J Am W Works Assoc 105(5):104-105

Remini B, Achour B, Kechad R (2011) Traditional techniques for increasing the discharge from qanats in Algeria. J irrig drain syst (Springer) 25(4):293-306 